\title{
EMPLOYMENT EQUITY IN TERTIARY EDUCATION: THE PITFALLS OF FAST-TRACKING ACADEMICS
}

\author{
J. Geldenhuys \\ Department of Mercantile Law \\ University of South Africa \\ Pretoria, South Africa \\ e-mail: geldej@unisa.ac.za / https://orcid.org/0000-0001-9956-7071
}

\section{ABSTRACT}

During 2018, the South African Human Rights Commission (SAHRC) was requested to hold investigation hearings at the University of South Africa (Unisa). The purpose was, among other things, to provide solutions to problems relating to the lack of meaningful transformation in employment in the institution. Before the finalisation of the investigation hearings, Unisa management began the process of amending the institution's Employment Equity plan. This contribution, against the setting of the recommendations made for Unisa, considers the different measures that could be implemented to speed up the transformation of the academic workforce in South African universities. After scrutinising the relevant pedagogic, legal and social implications of the implementation of different affirmative action measures, several potential pitfalls or potentially negative consequences of affirmative action measures not promoting the academic project are identified. It is concluded that developing an individual into a mature academic should not be forced or fast-tracked because of the possible negative consequences for both individuals and the academic project as a whole. Moreover, making academic appointments and promotions without considering crucial factors such as experience, publications and knowledge is bound to have a devastatingly negative impact. Enhancing the skills of employees in the designated groups would appear to be the best way of levelling the academic playing field.

Keywords: affirmative action, employment equity, Employment Equity plan, fast-tracking academic development, transformation in employment, substantive equality, transformation in tertiary education

\section{INTRODUCTION}

Late in 2017, the Vice Chancellor (VC) of the University of South Africa (Unisa) requested the South African Human Rights Commission (the SAHRC) to consider the viability of Unisa's Employment Equity (EE) plan, its affirmative action measures and the way in which they are implemented. (The scope of the investigation hearings at Unisa covered issues besides EE, such as the workplace disciplinary action policies, and alleged claims of racism, bullying and harassment in the Unisa College of Law (CLAW). These are not discussed here).

With reference to the recommendations that were made by the SAHRC, this article 
highlights some of the potentially negative effects of the premature (it is felt) and unlawful policy changes that have been proposed in the CLAW. It is also an urgent appeal to the Minister of Higher Education to investigate and to provide guidance on the methods that ought to be used by higher-education institutions to promote EE in order to avoid what can potentially become a national catastrophe in tertiary education. The Department of Higher Education and Training (DHET) is mandated in terms of section 3 of the Higher Education Act 101 of 1997, as amended by the Higher Education Amendment Act 9 of 2016, to adopt policies and to monitor and oversee the implementation of transformation initiatives at tertiary-education institutions. The DHET, the Department of Labour and the Employment Equity Commission can all help to ensure that the Human Resource policies of tertiary education institutions are amended where necessary and implemented in a manner that is not driven by rigid quotas. This approach was proposed during the meeting concerning the implementation of the SAHRC 2016 National Report on transformation at public universities in South Africa (see Parliamentary Monitoring Group 2018).

\section{BACKGROUND}

Inequitable representation is a problem that is having to be grappled with generally in tertiary education. This was the reason why the SAHRC investigated barriers to transformation at a national level (Parliamentary Monitoring Group 2018). In the Department of Labour (20172018) Annual Report there was a separate exposé of the EE position of universities and other tertiary-education institutions. The statistics clearly show that, particularly at senior and managerial levels, white men and women are, in general, severely over-represented (Department of Labour 2017-2018, 39-40). A corrollary is that, according to the statistics, whites undergo the most training (Department of Labour 2017-2018, 41, 46). White women, who are markedly the most over-represented at the higher occupational levels, are reported to receive the most training and development opportunities. The data also show that white men and white women are promoted the most: in 2016, 45,5 per cent of promotions were in the white population group, 23,5 per cent black Africans, 6,5 per cent Indian and 5,7 per cent coloured people (Department of Labour 2017-2018, 45). Affirmative action is generally applied more strictly during the appointment phase: most new appointees are black persons $(41,7 \%)$ followed by whites (26,8\%) and foreigners (18,7\%) (Department of Labour 2017-2018, 45).

As for Unisa's EE statistics for 2018, there are very few black full or associate professors in the CLAW, with many black employees having been appointed into the lower ranks (SAHRC Final Report 2018b, item 3.56). At the lower levels of junior and senior lecturer, gender presents a greater obstacle than race (CLAW EE plan 2016-2020). Measured against the national 
statistics for the Economically Active Population (EAP), the academic profile in the CLAW is as follows (see Table 1): At post grade 5 (full professor) level, white males and females are severely over-represented: there were 22 white males and 21 white females in 2018 . The statistics show that there were only two black African male full professors and one female black African full professor in 2018. There was only one male Indian full professor and no female Indian full professors. In 2018 there were no coloured full professors in the CLAW. Foreign nationals accounted for three of the 50 full professors: two males and one female. The majority of the academics at post grade 8 (lecturer) level (total: 46) are black Africans, some 31 of the 63 academics at this level in 2018 were male black Africans and 15 black African females were employed as lecturers in 2018. Five white males and seven white females were lecturers in the CLAW. There are no male coloured or Indian lecturers, and only one coloured and one foreign national female academic. Three female Indian academics are working at post grade 8 level. Overall, measured against the EAP, male black African academics in the CLAW are underrepresented by 11,4 per cent and females by 20 per cent; coloured academics are underrepresented by 5,4 per cent (male) and 3,5 per cent (female) respectively. In contrast, Indians and whites are over-represented: Indian males by 0,9 per cent and females by 2,6 per cent, white males are over-represented by 10,1 per cent and white females are over-represented by 22,7 per cent.

The statistics clearly points towards the fact that Unisa strictly applies EE in the appointment of new academics, but that these appointments are usually made in the lower ranks.

Table 1: Academic EE profile at the CLAW, 2018

\begin{tabular}{|c|c|c|c|c|c|c|c|c|c|c|c|c|}
\hline \multirow{2}{*}{$\begin{array}{c}\text { Occupational } \\
\text { Levels }\end{array}$} & \multirow{2}{*}{ 范 } & \multicolumn{4}{|c|}{ Male } & \multicolumn{4}{|c|}{ Female } & \multicolumn{2}{|c|}{$\begin{array}{l}\text { Foreign } \\
\text { National }\end{array}$} & \multirow{2}{*}{ 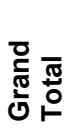 } \\
\hline & & African & Coloured & Indian & White & African & Coloured & Indian & White & Male & Female & \\
\hline \multirow{3}{*}{$\begin{array}{c}\text { Senior } \\
\text { Management } \\
\text { level }(1-3) \\
\end{array}$} & 1 & & & & & & & & & & & 0 \\
\hline & 2 & & & & & & & & & & & 0 \\
\hline & 3 & & & & & & & & & & & 0 \\
\hline \multirow{3}{*}{$\begin{array}{c}\text { Professionally } \\
\text { qualified } \\
\text { level }(4-6) \\
\end{array}$} & 4 & & & & & & & & & & & 0 \\
\hline & 5 & 2 & & 1 & 22 & 1 & & & 21 & 2 & 1 & 50 \\
\hline & 6 & 5 & & 2 & 4 & 3 & & 1 & 13 & 1 & 2 & 31 \\
\hline \multirow{6}{*}{$\begin{array}{c}\text { Skilled } \\
\text { technical and } \\
\text { academically } \\
\text { qualified } \\
\text { level (7-12) }\end{array}$} & 7 & 27 & & 4 & 7 & 9 & 1 & 5 & 26 & 1 & 3 & 83 \\
\hline & 8 & 31 & & & 5 & 15 & 1 & 3 & 7 & & 1 & 63 \\
\hline & 9 & & & & & & & & & & & 0 \\
\hline & 10 & & & & & & & & & & & 0 \\
\hline & 11 & & & & & & & & & & & 0 \\
\hline & 12 & & & & & & & & & & & 0 \\
\hline \multirow{4}{*}{$\begin{array}{c}\text { Semi-skilled } \\
\text { level (13-16) }\end{array}$} & 13 & & & & & & & & & & & 0 \\
\hline & 14 & & & & & & & & & & & 0 \\
\hline & 15 & & & & & & & & & & & 0 \\
\hline & 16 & & & & & & & & & & & 0 \\
\hline \multirow{3}{*}{$\begin{array}{c}\text { Unskilled } \\
\text { level (17-19) }\end{array}$} & 17 & & & & & & & & & & & 0 \\
\hline & 18 & & & & & & & & & & & 0 \\
\hline & 19 & & & & & & & & & & & 0 \\
\hline $\begin{array}{l}\text { Temporary } \\
\text { employees }\end{array}$ & 99 & 19 & & & 5 & 14 & 1 & 1 & 7 & & & 47 \\
\hline Grand Total & & 84 & 0 & 7 & 43 & 42 & 3 & 10 & 74 & 4 & 7 & 274 \\
\hline
\end{tabular}

Source: CLAW EE plan 2016-2020. 
Table 2. Representativity by race.

\begin{tabular}{|l|c|c|c|c|c|c|c|c|}
\cline { 2 - 9 } \multicolumn{1}{c|}{} & \multicolumn{4}{c|}{ Male } & \multicolumn{4}{c|}{ Female } \\
\cline { 2 - 10 } \multicolumn{1}{c|}{} & African & Coloured & Indian & White & African & Coloured & Indian & White \\
\hline Overall \% & 30.7 & 0.0 & 2.6 & 15.7 & 15.3 & 1.1 & 3.6 & 27.0 \\
\hline EA \% & 42.1 & 5.4 & 1.7 & 5.6 & 25.3 & 4.6 & 1.0 & 4.3 \\
\hline UNDER/ OVER & -11.4 & -5.4 & 0.9 & 10.1 & -20.0 & -3.5 & 2.6 & 22.7 \\
REPRESENTED & -11.4 & & & &
\end{tabular}

Source: CLAW EE plan 2016-2020

During the Unisa investigation hearings in 2018, the SAHRC was required to scrutinise Unisa's EE plan and the processes followed in adopting the policies (item 3.2.1 of the Terms of Reference (SAHRC 2018c)). Moreover, the SAHRC had to determine whether the EE plan complies with the Constitution of the Republic of South Africa, 1996 (the Constitution) and whether it provides for sufficient measures for redress in its appointment and promotion policies for those who were previously disadvantaged (items 3.2.2-3.2.6 of the Terms of Reference (SAHRC 2018c)). Furthermore, the SAHRC had to consider whether the measures that are established to promote EE set quotas or impermissible absolute barriers, or whether one group of employees is impermissibly being preferred to the detriment of others. Another question the SAHRC was requested to answer was whether, as it stands, the CLAW EE plan is potentially capable of promoting representivity in the workplace, (item 3.2.7 of the Terms of Reference (SAHRC 2018c)) and whether the appointment of a black Acting Executive Dean or Executive Dean would promote equity (item 2.8 of the Terms of Reference (SAHRC 2018c)). The crux of this enquiry was the question whether not having appointed a white female as Acting Executive Dean solely because she is white amounted to unfair discrimination (item 3.2.9 of the Terms of Reference (SAHRC 2018c)).

The SAHRC also had to investigate instances where the EE plan or the affirmative action policies infringed the human dignity of non-designated groups and consider to what extent the CLAW policies promote diversity and social cohesion. Moreover, the SAHRC had to consider whether, on the evidence presented, the measures intended to promote racial transformation in the CLAW are in fact effective (item 3.2.13 of the Terms of Reference (SAHRC 2018c)).

The SAHRC extended the scope from the CLAW only to cover the whole of Unisa (SAHRC Final Report 2018b, item 2.7; cf SAHRC 2018a). Furthermore, the Commission indicated that it would conduct similar investigations at all tertiary education institutions in South Africa. Accordingly, the outcome of the Unisa investigation hearings and the recommendations made is also of importance for other tertiary education institutions. 


\section{THE PROPOSALS OF THE SAHRC AND IN THE CLAW}

Unsurprisingly, the SAHRC's report indicates that there is a lack of sufficient racial transformation at Unisa. The proposals for addressing the concerns include reviewing Unisa's governance models (SAHRC Final Report (2018b), items 5.3-5.5) to ensure that barriers to transformation are removed (SAHRC Final Report (2018b), items 5.6-5.10). Most of the questions posed in section 2 above have been left unanswered by the SAHRC.

While the SAHRC investigation hearings were being held, certain "interventions" to address the racial employment inequalities in the CLAW were already being strategised. Before the SHRC's report was made available, a policy document was circulated, discussed and presented for approval to the university's Senate. The policy proposes several methods through what is called a "radical transformation programme" to address the slow progress in promoting representivity of the black cohort, particularly at the higher academic levels. The various proposed affirmative action measures are set out below.

\section{THE PROBLEMS WITH DIFFERENT METHODS OF PROMOTING DESIGNATED GROUPS OF EMPLOYEES}

Five proposals have been made in order to facilitate "radical transformation" in the CLAW:

(a) improving the performance of the management of affirmative action;

(b) placing a moratorium on the appointment of non-designated employees or those falling in groups that are over-represented until representivity is achieved;

(c) requiring white academics to transfer skills or mentor black academics before they will be eligible for appointment on a contract at the institution after their retirement;

(d) lowering of the appointment and promotion criteria for designated groups of employees who are not over-represented in order to fast-track their attaining professorial status;

(e) suspending or practically excluding ad hominem promotion of over-represented groups;

These proposals are set off and measured against specific recommendations that were made by the SAHRC, where possible, to determine their viability and to identify potential stumblingblocks to their implementation. They are expanded upon in what follows.

\section{Sharpening up the management}

In order for radical transformation to succeed, affirmative action measures must be implemented and managed in a manner that is careful, sensitive and ethical. As a starting-point, strong and efficient management providing firm leadership is essential. The SAHRC Final 
Report indicates that the $\mathrm{VC}$, as the university's accounting officer, is responsible for implementing the affirmative action measures (SAHRC Final Report (2018b), item 5.3). However, there appear to be gaps on the strong leadership front at Unisa. The VC, by his own account, had apparently buckled to the whims of a group of black academics at a meeting when he appointed a black professor who had previously served as Director of the CLAW instead of following the prescribed procedures. He claimed that this had been "a once off exercise in response to the volatile environment at the CLAW" (SAHRC Final Report (2018b), item 3.17).

To ensure that the policies are implemented properly, the university's EE Office must oversee the programme. Management is responsible for rigorously monitoring and reporting on the progress made. The affirmative action measures must be deliberated on with the employees. This transparency will serve to instil trust in management and potentially decrease the number of disputes concerning affirmative action that are referred for resolution.

In addition, managing EE would hopefully address certain deviations from what is legally required when adopting and implementing affirmative action; these deviations were exposed during the Unisa investigation hearings. Concerns were raised regarding Unisa's failure to abide by its own policies and procedures in making appointments (SAHRC Final Report (2018b), item 3.16), a failure that was evidenced by the fact that unions are not invited to interviews for directors and deans (SAHRC Final Report (2018b), item 3.9), that management made no effort to retain highly qualified black academics (SAHRC Final Report (2018b), item 3.10), and that the placement of individuals in acting positions was made without following the institution's policy or referring to the EE plan (SAHRC Final Report (2018b), item 3.30).

\section{Requiring mentoring/skills transfer for eligibility for post-retirement contracts}

This affirmative action requirement is dubious for several reasons. From the SAHRC Final Report, it is apparent that black academics are not comfortable with "being led" by a white academic and do not acknowledge the value of white leadership as they feel that whites are "generally insensitive to the plight and marginalisation of black staff members" (SAHRC Final Report (2018b), item 3.14). The Black Forum opposes the idea of forging mentoring relationships and skills transfer from white to black staff. Their submission to the SAHRC Final Report reads:

"There is a mood of perpetual supervision by whites over blacks and this creates a sense of entitlement, where white people feel that they are entitled to higher positions where they manage and supervise black people" (SAHRC Final Report (2018b), item 3.52.5). 


\title{
Focused training of designated groups of employees and of those falling in under-represented groups
}

In its Final Report, the SAHRC stresses the importance of providing training to build the capacity of "designated groups" of employees:

\begin{abstract}
"Universities should take measures to accelerate the process of training and developing young academics, to enable them to qualify for more senior positions, with a particular focus on previously disadvantaged professionals. However, care must be taken to ensure that employment equity objectives are not limited to changing the demographics alone, but must ensure that persons appointed to the relevant posts are adequately capacitated to deliver at the level at which they have been appointed in order to achieve substantive transformation" (item 5.9 of the SAHRC Final Report (2018b); emphasis added).
\end{abstract}

The solution may lie in providing more and better focused training to employees in the designated groups. The Code of good practice on the preparation, implementation and monitoring of the EE plan (the Code) (Department of Labour 2017) stresses the necessity of providing training. The Code proposes that "designated employers" must provide employees in the designated groups with training so as to help them to meet the required standards in order that they will be able to work and progress in the workplace (Du Plessis and Fouché 2015, 158). Not to provide the training necessary to address deficiencies in competency could be construed as an unfair labour practice (section 186(2) of the Labour Relations Act 66 of 1995; cf Monyakeni v SA Police Service 2008 (29) ILJ 3111 (BCA) and Lotter v SA Police Service 2005 (26) ILJ 578 (BCA)). The highest court in South Africa, the Constitutional Court, in SAPS v Solidarity obo Barnard (Police and Prisons Civil Rights Union as Amicus Curiae) 2014 (6) SA 123 (CC) (hereafter cited as SAPS v Solidarity obo Barnard (CC)) also emphasised the importance of training and development .

In 2018, the CLAW had 15 black professors and 59 white professors (SAHRC Final Report 2018b, item 3.54). Although these numbers do not reflect the racial profile of the EAP, progress has been made and continues to be made towards that end. Several initiatives have been undertaken to rectify the skewed racial profile at the higher levels. They include writing retreats, establishing mentoring in research and reading groups, allowing black academics time off from tuition to enable them to work on their postgraduate studies at home, and research and flagship programmes that focus on promoting and accessing opportunities for academics in the designated groups of employees (SAHRC Final Report (2018b), item 3.53).

During the SAHRC investigation hearings at Unisa, the VC expressed his concern about the fact that the racial inequalities in the CLAW exist despite the progress that had been made through concerted efforts to promote black academics' skills and the substantial investment that 
had been made to provide training towards developing black academics. At Unisa the "Grow your own timber" programme, the Women in Research Awards, and development and training programmes that include the Academic Qualification Improvement Project are undoubtedly aimed at promoting black employees (SAHRC Final Report (2018b), items 3.56, 3.57 and 3.64). The national "New Generation of Academics" programme (nGAP) is another new project aimed at "fast-tracking" black academics to the status of full professor. These initiatives have paid off, but change has been slow. Clearly, the legislature also did not envisage that radical racial transformation would occur instantaneously in South African. This is bolstered by the fact that in their EE reports employers are required to provide progressive transformation milestones for the implementation of their EE plans.

\section{Placing a moratorium on the appointment and promotion of employees not falling in the designated groups}

The SAHRC, in its Final Report, recommends that Unisa should prioritise the recruitment of academics who fall into the previously disadvantaged and under-represented groups, and that once the "transformation target has been reached", the cap placed on non-designated and overrepresented groups of employees must be removed so that these employees "are not completely excluded from opportunities" (SAHRC Final Report (2018b), item 5.7).

In other words, the instruction is to prefer employees falling within the "designated groups" who are recognised as being previously disadvantaged over those who do not fall into the designated groups (non-designated employees). However, the SAHRC goes further by specifying that those being preferred in the CLAW must, in addition, fall into a group that is under-represented. "Designated groups" of employees is defined in section 1 of the Employment Equity Act 55 of 1998 (the EEA) as meaning "black people, women and people with disabilities". The only group of employees who do not qualify as falling within the "designated groups" of employees is white able-bodied men.

Not being a beneficiary of the affirmative action measures does not exclude a nondesignated employee from protection against unfair discrimination, however. In terms of section 5 of the EEA, employers are obliged to "take steps to promote equal opportunity in the workplace by eliminating unfair discrimination in any employment policy or practice". Race, sex and disability are also included in the listed or prohibited grounds for discrimination (section 6 of the EEA). The SAHRC failed to acknowledge this fact in its Final Report. No finding is presented regarding the aptness of the measure that has been applied in the CLAW to overlook white men for promotion even though they meet and even exceed the objective promotion criteria (the allegation is merely noted in the SAHRC Final Report (2018b), item 


\section{$3.41)$.}

The SAHRC was also required to consider whether the reasons for and the way in which Unisa had gone about appointing a black Acting Executive Dean amounted to unfair discrimination. This appointment had been made instead of allowing the white female Deputy Dean, as is customary, to step up to the acting position after the end of the previous Executive Dean's term. Unfortunately, the SAHRC also failed to make a finding on this point. However, in its submission, Solidarity argued convincingly that a white female also falls within the "designated groups" of workers and is similarly entitled to preferential treatment. To tell a white woman that a position is "reserved for a black person" amounts to unfair discrimination (SAHRC Final Report (2018b), item 3.217). I can see no reason why it would not qualify as unfair discrimination if a white man were told that a position was "reserved for a black person" too, because the Constitutional Court has held that the reservation of positions on the basis of race is prohibited (SAPS v Solidarity obo Barnard (CC) at paras 26, 55-56; see, too, the discussion under subsection 5.2 below).

\section{Suspension of the ad hominem promotion of employees falling in groups that are over-represented at a particular employment level}

Another related affirmative action measure which was proposed in the CLAW policy document in order to address the racial and gender inequity at the higher academic levels of associate professor and professor is the suspension of promotions of academic employees who do not fall in the "designated groups" of employees, or in those groups who are over-represented (CLAW EE plan 2016-2020, 32). This came to fruition. On 30 November 2018 an announcement was placed on the Unisa intranet indicating that Unisa management had decided to postpone ad hominem promotions in anticipation of a report of an Academic Promotions Transformation Task Team commissioned by the Executive Committee of Senate (Senex). Since the end of 2018 and in the absence of a valid, approved EE plan, a complete bar has effectively been placed on the promotion of white men and women in the CLAW.

The fact that this affirmative action measure was implemented in the absence of an accepted EE plan was undeniably premature. As a consequence of this embargo, the employees who were eligible to apply for promotion in October 2018 have been denied the opportunity to do so. To address this, the adopted policy document makes provision for retrospective implementation so that those who would have been promoted from 1 January 2019 would not be adversely affected. However, this does not address the issue of white males (who do not fall in the "designated groups") and other employees who do fall in the "designated groups" but who are over-represented at the next post level. Clearly, this is neither lawful nor fair. The 
Labour Appeal Court described the purpose of promotion as follows:

"The purpose of promoting an employee is usually because the employer's organisation has a vacancy for a person to perform a particular task and candidates for promotion are employees functioning at a lower level who possibly have the qualifications, skills and ability to perform the tasks of the higher position" (Ncane v Lyster (2017) 38 ILJ 907 (LAC) at para 24).

In considering the viability of this affirmative action measure, it is important to ponder the peculiar nature of promotion in the academic context. Whereas promotions are usually competitive, that is, there are a certain number of open positions or vacancies at a higher level for which persons from inside, or both inside and outside, the workplace compete, ad hominem promotion that is used in several South African universities is dependent on the performance and progress of an individual. (For an in-depth discussion of the differentiation between $a d$ hominem promotions and competitive promotions refer to Geldenhuys 2018.) At Unisa, EE targets are irrelevant when it comes to ad hominem promotions. The suitability of the applicant is measured against a personnel point system. The criteria are objective. Therefore, it would be unfair discrimination if an academic were denied promotion based on their race and/or gender or for their lack of a disability (section 6 of the EEA; SAHRC Final Report (2018b), item 3.55).

\section{Fast-tracking by lowering appointment and promotion criteria}

The institutional "Guidelines for the minimum criteria for appointment and promotion of academic employees" and the criteria that are applied to all academics in the CLAW are viewed as being unfair towards black academics. They see them as a "gate-keeping" measure aimed at excluding them for the purposes of ad hominem promotion.

To respond to this concern, it was suggested that for applicants for appointments and for candidates for promotion falling in the "designated groups" of employees who do not fall in groups that are over-represented, the publication and supervision requirements must be lowered or removed. But this type of affirmative action measure has several unintended negative effects. First, zooming in on the key performance areas (KPAs) of publication and supervision is to look at what is required of an academic in a one-dimensional manner. This does not take account of the range of KPAs by which an academic can be assessed. Moreover, it creates the impression that the identified KPAs are general shortcomings in the competencies of black academics. This will undoubtedly reflect badly on the integrity of the academic project and affect the reputation of the tertiary education institution undesirably.

Most, if not all of the affirmative action measures that are set out above are aimed at speeding up transformation of the workplace by fast-tracking academic development. But the 
very notion of fast-tracking academic development is problematic, as is argued below.

\section{PROBLEMS ASSOCIATED WITH FAST-TRACKING ACADEMIC EMPLOYEES}

There are several potential risks associated with fast-tracking academics. The various factors that must be borne in mind when adopting affirmative action measures are discussed under separate headings below: they are grouped under legal considerations, the negative impact on dignity/reputation and pedagogic considerations.

\section{Legal considerations}

Adopting and applying affirmative action measures based solely on race, arbitrarily is not legal and does not pass constitutional muster (see section 9(2) of the Constitution; Gordon v Department of Health, KwaZulu-Natal [2004] 7 BLLR 708 (AH) at para 17; Solidarity v Department of Correctional Services (2016) 37 ILJ 1995 (CC) at paras 64, 82, 118; cf Gnade 2018). Unfortunately, save for noting a white female lecturer's concern regarding the manner in which affirmative action is being applied in the CLAW, the SAHRC appears to be completely oblivious to or undecided about the legal requirements for the application of affirmative action in a tertiary-education institution (SAHRC Final Report (2018b), items $3.39-3.40$ ).

What must be achieved in transforming the academic workforce in a tertiary-education institution is that the demographic profile must be changed in a lawful manner. In other words, the institution must change the racial profile without acting in a way that constitutes unfair discrimination.

The EEA requires "designated employers" such as Unisa to implement affirmative action measures. ${ }^{1}$ It is legally permissible to favour employees falling within the "designated groups" of employees (see the definition in section 1 of the EEA). However, affirmative action measures were not intended to be used as means of awarding titles and positions to persons falling in the designated groups or to punish workers who do not fall into the designated groups. Rather, the purpose is to remove discriminatory practices in the workplace and to provide designated groups of employees with equal opportunities in the workplace (Stoman v Minister of Safety and Security 2002 (3) SA 468 (T) at 477F-H). Another aim is to promote representivity so that the country's employed popultation reflects the composite population's demographics (section 15 of the EEA). Bozzoli explains that achieving representivity in a tertiary-education institution is not an easy feat, because the staffing is in any event not balanced in these institutions. She describes the three "tiers" of academic staff: the bottom tier, consisting of junior academics, must develop in order to move up to the middle tier consisting of developing academics; and, eventually, they can rise to the top tier, which is a small constituency of senior, mature associate 
professors and professors. She refers to this upward trajectory as the natural "accretion of knowledge, expertise and experience over time". Bozzoli bemoans the fact that Unisa has lost sight of the fact that the middle tier, which is supposed to replace the top tier, is shrinking. This situation could, in her opinion, steer Unisa towards a crisis when the senior professor corps becomes depleted as a result of retirements and resignations (Bozzoli 2018).

Although Unisa is legally obliged to compile and implement an EE plan (section 15(1) of the EEA) in which numerical targets are set (section 15(2) read with section 2 of the EEA), strict quotas barring the appointment or promotion of non-designated employees is prohibited (section 15 of the EEA; SAPS v Solidarity obo Barnard (CC) at paras 42, 52). If an EE plan indicates groups that are under-represented and over-represented at the various employment levels, as Unisa's EE plan does, the Constitutional Court has confirmed that if a certain group is over-represented in the workplace, the right of that group to compete for appointment in the workplace can be negated until such time as demographic goals have been achieved (SAPS $v$ Solidarity (CC) at paras 42,87$)$. This principle applies equally in respect of black Africans, coloureds, Indians and persons with disabilities, regardless of sex (SAPS v Solidarity (CC) at para 88). A representative of the EE Office indicated that the national EAP targets are used to set the representivity targets. To establish whether a certain group is over- or under-represented, each occupational level is considered (SAHRC Final Report (2018b), item 3.29). At Unisa currently, white female academics were over-represented by some 37,4 per cent and coloured males were over-represented by 2,9 per cent (SAHRC Final Report (2018b), item 3.28).

What is apparent is that in drafting the EE plan, regard must be had to the underrepresentation and over-representation of different racial groups and persons with a disability, but also to gender disparity. However, the Constititutional Court expressly declared that if numerical targets in EE plans are pursued too rigidly, it amounts to the reservation of positions, which is prohibited (SAPS v Solidarity bob Barnard (CC) at paras 65-66). Moreover, affirmative action should promote all of the groups of designated employees and not only one group at the expense of the others (SAPS v Solidarity obo Barnard (CC) at para 88). On top of that, other factors besides race, sex and disability must be considered in designing and implementing an affirmative action policy. Factors that must be considered include:

(a) the rights of non-designated groups of employees (see SAPS v Solidarity obo Barnard (CC) at para 148);

(b) fairness;

(c) the impact on the dignity of individuals from the designated and non-designated groups of employees (SAPS v Solidarity obo Barnard (CC) at paras 30-32, 38); 
(d) the long-term goal of non-racialism and a non-sexistic and socially inclusive society (SAPS v Solidarity $(\mathrm{CC})$ at paras 77,148$)$

(e) the promotion of efficiency in the workplace;

(f) the suitability of the candidate and their relative merits (SAPS v Zandberg 2010 (2) BLLR $194(\mathrm{~A}))$.

In Du Preez v Minister of Justice and Constitutional Development 2006 (3) All SA 271 (SE) the court stressed the importance of considering, besides the level of representivity, factors including experience, knowledge, leadership qualities and managerial skills. Affirmative action measures that are based on race or sex alone, and which are applied in an arbitrary manner in order to benefit a certain group of employees at the expense of others, do not comply with the constitutional requirements (see SAPS v Solidarity obo Barnard (CC) at para 140).

Examples of unlawful implementation of an EE plan were provided during the Unisa investigation hearings. A coloured female working at Unisa indicated that she had repeatedly applied for other positions in the institution, but that she was not considered for the positions based on her race (SAHRC Final Report (2018b), item 3.11). A white female employee also alleged that she had worked at Unisa for over a decade, but that, despite the fact that she was better qualified for a certain position, she was not appointed to a post for which she had applied based on her race (SAHRC Final Report (2018b), item 3.12). If it is true that Unisa has implemented rigid quotas that are having such a long-term effect, particularly when the individuals were the most suitable candidates for appointment in those positions, the institution would clearly have failed to meet its legal and social obligations as a higher-education institution.

\section{Negative impact on dignity/reputation}

The SAHRC was supposed to make findings and to put forward workable proposals for measures that Unisa can use to "eradicate social and economic inequalities" (item 4.1 of the Terms of Reference (2018c)). One of the intended outcomes of the investigation hearings was for the SAHRC to make proposals that would advance social cohesion and guarantee that the interests of students and staff are placed first, to ensure that the constitutional rights of all stakeholders are protected and that the mechanisms

"encourage the forging of human relations at the CLAW that are premised on respect, care, and compassion, and are guided by the principles of equality, fairness, equity, social progress, justice, human dignity, and freedom" (item 4.6 of the Terms of Reference 2018c). 
Affirmative action measures are approached with the view of levelling the playing field by facing up to issues that had led to past injustices in a systematic and holistic manner. But what does it mean to "level the playing field"? And when will the process of transformation be completed? Perhaps the answer lies in the definition of "transformation" in the higher-education context.

During the Unisa investigation, the SAHRC failed to provide a definition. However, the SAHRC had previously defined it as follows:

"The creation of a system of higher education which is free from all forms of unfair discrimination and artificial barriers to access and success, as well as one that is built on the principles of social inclusivity, mutual respect and acceptance" (SAHRC 2016, 7).

The SAHRC must, in the exercise of its functions, endorse values contained in international human rights conventions (section 13(b)(vi) and (vii) of the SAHRC Act). South Africa has ratified the International Convention on the Elimination of All Forms of Racial Discrimination, 1969 (the ICERD; see United Nations Human Rights Commission (UNHRC) 1969 "Status of ratification, Reservations and declarations"). The ICERD defines "racial discrimination" as follows:

"any distinction, exclusion, restriction or preference based on race, colour, descent, or national or ethnic origin which has the purpose or effect of nullifying or impairing the recognition, enjoyment or exercise, on an equal footing, of human rights and fundamental freedoms in the political, economic, social, cultural or any other field of public life" (Part 1 , article 1 of the ICERD).

Affirmative action measures are excluded from the ambit of "racial discrimination" (article 4 of the ICERD). However, article 4 also determines that the exclusion applies to the extent that the affirmative action measures

"do not, as a consequence, lead to the maintenance of separate rights for different racial groups and that they shall not be continued after the objectives for which they were taken have been achieved."

The Black Forum, in its submission to the SAHRC during the Unisa investigation, indicated that "meaningful transformation" is not based on numerical targets. Instead, it is the process of challenging "discriminatory policies, culture, white supremacy and traditions" (SAHRC Final Report (2018b), item 3.52.3). This clearly shows that the intervention that is being sought goes beyond achieving equal treatment in the workplace. What would the implications be for the 
reputation of the CLAW, Unisa and the profession if the different affirmative action measures were to be implemented? Vice has considered the ethical and moral considerations that arise from balancing the conflicting values of dignity, equality and fairness when affirmative action measures are implemented, and indicates how often the conflicts presented are unresolvable (Vice 2015, 135ff).

As mentioned above, the SAHRC recommends that Unisa must recruit persons in the "designated groups" of employees that are under-represented until such time as the "transformation target has been reached". Removing the cap once the targets are achieved would, in the SAHRC's opinion, be sufficient to show that non-designated employees "are not completely excluded from opportunities" (SAHRC Final Report (2018b), item 5.7). But would the inequities be remedied by prevent white employees from progressing to the higher levels in the workplace for an indefinite period? This question is moot. Employers are, not even in accordance with an adopted, valid EE plan, permitted to bar the work progression of employees in the non-desiganted groups that comply with the requirements for promotion based on their race and/or sex for any amount of time. To place an absolute barrier in the path of nondesignated groups would not correspond to the purpose of affirmative action (Solidarity obo Barnard v South African Police Service 2014 (2) SA 1 (SCA) at para 78; SAPS v Solidarity obo Barnard (CC) at para 26).

The following hypothesis is derived from the facts in SAPS $v$ Solidarity obo Barnard (CC) and adapted to a situation in a tertiary education. Assume that a white female lecturer, Ms A, complies with the requirements for a senior lecturer position. Even though white women are over-represented at the level of senior lecturer, she applies for ad hominem promotion. According to the Constitutional Court, employers may decline to promote applicants who fall in a designated group of employees that is over-represented in the workplace in that category or level of work. However, in the case of ad hominem promotions candidates rely on their own personal performance and progress. In practical terms, Ms A would not be able to apply successfully for promotion unless she becomes disabled or changes her race until sufficient academics in the under-represented categories have been promoted. This means that Ms A's progress is made dependent on others' performance and not her own. She is also denied the possibility of contending for promotion on objective criteria. Unless a time limit for the implementation of the affirmative action measures is set, this could potentially hamper Ms A's progress perpetually, or apply to every consecutive level of employment. Meanwhile, Ms A will not be earning the salary that she should, she has had her status reduced and if she were to apply for a position at a different tertiary education institution, she would, if they were to consider appointing white females, only be considered for the position of lecturer, even if she 
were to meet the criteria for senior lecturer. It also reflects badly on an employee if his or her employer does not promote him or her, despite him or her meeting the requirements for the next post level. (This example is also to be found in Geldenhuys 2018.)

The outcome of lowering the appointment and promotion criteria for some academics in an institution, or of placing stumbling-blocks in the academic career paths of other groups can also pose a risk to the beneficiaries of the affirmative action measures. In academia, peer validation of competence plays an important role. Becoming an active member of the academic community requires the novice academic to teach, to mimic senior colleagues and to develop their knowledge, to make a debut at a conference, to write a research article, and to be both subjected to strenuous peer review and act as a peer reviewer. As for qualifications, they must be at least a step ahead of those whom they are expected to teach and must possess the competence to supervise before taking on postgraduate students. All of these roles and functions form part of the academic identity. Absent one step, and the candidate will be an academic in name only.

\section{Pedagogical considerations}

Several further potential risks are associated with fast-tracking academics, and they, too, should be borne in mind when adopting and implementing affirmative action measures at tertiaryeducation institutions.

\section{Negative effect on institutional research}

Applying a strict quota system and lowering the promotion criteria to exclude the requirement of conducting research would not necessarily promote or support institutional research.

Placing a moratorium on the promotion of certain groups of employees based on their race or sex, or simply because they are able-bodied, would possibly also negatively affect the number of research outputs produced by the affected academics. The reason for this is that the appointment or promotion requirements often include counting the number of outputs over a three- and/or five-year period. If an individual has no hope of promotion, there is little incentive to produce outputs in the form of academic articles, for instance.

\section{Negative impact on capacity to supervise postgraduate students}

Waghid $(2015,1-19)$ concludes that fast-tracking academics may compromise the quality of doctoral research. He states that the historical education context in South Africa heightens the risk associated with requiring inexperienced researchers to act as the promotors or supervisors of postgraduate research studies. 
Research and knowledge production are what define a university (see the abstract to Maistry 2017). Fast-tracking individuals based on race, or any other arbitrary ground, impedes both the development of supervision competence and the deep conceptual development of the young academic. If academics are not permitted to develop the necessary competencies, research students will inevitably be left with poor supervision, which, in turn, will result in substandard research proposals and dissertations. This contradicts the goals expressed by the Academy of Science of South Africa (ASSAf) $(2010,22)$ and aimed at strengthening South Africa's PhD profile.

\section{Negation of the perceived and real value of internal performance management}

Lowering the appointment and promotion criteria for all or a certain cohort of the designated groups of academic employees would contradict the benchmarks set by various tertiaryeducation institutions for the key performance areas of staff. In most universities, research and supervision are included in the key performance areas in the Internal Performance Management System (IPMS). If the Radical Transformation Programme were to be implemented and an individual were to be promoted to the position of senior lecturer or associate professor in accordance with the revised lower requirements, they would, within a matter of months of being promoted to the higher status, be in the awkward position of being required to publish no fewer than three articles in accredited journals in order to earn the required 3 out of 5 for research in their IPMS interview. This would clearly not alleviate the concern that was raised during the Unisa investigation hearings that the IPMS is "used as a punitive tool" and that "black staff were not scoring high scores" when compared to their white colleagues (SAHRC Final Report (2018b), item 3.62).

\section{Perceived lowering of standards}

Tertiary-education institutions have a duty as employers to provide their students with tertiary education of the highest order (McInnes $v$ Technikon Natal McInnes $v$ Technikon Natal [2000] 6 BLLR 701 (LC) at para 22). During the Unisa investigation hearings, the representative of the Human Resources Department testified that Unisa applies affirmative action measures to meet its EE targets as early as at the shortlisting stage (SAHRC Final Report (2018b), item 3.4). The effect of this is that, based on quotas, the best candidate may not even be interviewed (Bozzoli 2018). Unfortunately, the SAHRC failed to pronounce on whether this is an appropriate way of promoting EE.

In PSA v Minister of Justice (1997) 18 ILJ 241 (T)) it was confirmed that the application of affirmative action does not justify appointing someone who is incapable of performing the 
tasks associated with the particular work. Section 20(3) of the EEA determines that a person is "suitably qualified" for appointment to a position if they comply with one or more of the following requirements (in this regard, see paragraph 5.1.6 below):

- they must have the required formal qualfications;

- they must have previous learning or relevant experience;

- they must, within a reasonable period, be able to comply with the requirements of the position in order to be able to perform the work.

$\mathrm{EE}$, particularly in tertiary education, must be implemented in a manner that is rational, taking into consideration what is expected of tertiary educators and tertiary institutions. So far as the academic qualifications required for appointment and promotion are concerned, rationality requires that cognisance be taken of a simple premise: one cannot teach someone more than one knows oneself.

\section{Toxic environment and associated poor performance}

The incorrect application of affirmative action could have devastating effects on the morale and efficacy of workers in both the designated and the non-designated groups of employees. The Constitutional Court in SAPS v Solidarity obo Barnard (CC) confirmed that the application of affirmative action in the workplace may be emotionally taxing on employees (at paras 1, 74, 127). Research shows that EE appointments may lead to feelings of isolation and group polarisation, a loss of motivation culminating in decreased productivity and a lowering of standards, and a revolt against the management (Strauss 2006, 51-52). Long-term effects can include the perception of reverse discrimination and the enforcement of racism (Strauss 2006, $53-54)$

Several of these consequences are visible at Unisa. The morale of academics is low. The toxic state, particularly in the CLAW, is palpable. The fact that EE has not been applied in a manner that is fair and transparent has led to distrust. In 2018, warnings were issued to academics regarding the high level of absenteeism, and there was also an unprecedented exodus of competent, highly qualified black academics to join academic institutions that require and promote research (SAHRC Final Report (2018b), items 3.8 and 3.31-3.33; cf Burger 2017, 9). The National Education Health and Workers' Union, in its submission to the SAHRC, stated that the reasons for the resignation of some 15 to 20 academics with doctorate degrees included that "the environment was suffocating and stifled their growth" (SAHRC Final Report (2018b), 
item 3.32). Currently, the CLAW is not an environment that is conducive to teaching, research and community engagement, and it is unsurprising that it is not optimally delivering on its social mandate.

\section{Educational equality not promoted}

Admittedly, the shortfall in the black cohort of academics holding postgraduate degrees can be addressed only if black students are encouraged to continue with further studies after completing their undergraduate degrees. However, the proposed imperatives often contradict considerations regarding the enhancement of quality.

Fast-tracking young black academics by setting the bar lower than for their white colleagues, and for academics at other tertiary-education institutions, is not a sound strategy for promoting educational equality. At several other universities, a PhD or an LLD is the minimum qualification for teaching at university level.

In the Faculty of Law at the University of Pretoria, for instance, in order to be a junior lecturer, one must have a master's degree in the particular field of law and at least be registered for an LLD degree; in addition, one must be able to prove that progress has been made towards completion of the degree. This means that the candidate must have presented papers at national conferences and be recognised by their peers. Moreover, teaching experience is taken into consideration, and having published at least two peer-reviewed articles is set as a recommendation. To be a senior lecturer, an LLD is required together with more than five years' teaching experience at a tertiary level. The incumbent must have at least eight publications in books or articles behind them that have been subjected to peer review. On top of that, they must have taught at a postgraduate level and have supervised postgraduate students to the completion of their dissertations. Form this level upwards, the candidate must have delivered papers at both national and international conferences. Besides having an LLD, an associate professor is expected also to have at least eight years' teaching experience. In addition, the candidate has to show proof of being involved in curriculum development, to have published 16 scholarly books or chapters in scholarly books or accredited journals, six of which must have been published in the preceding three years. They must also preferably have a National Research Foundation rating or be acknowledged as an established researcher.

The University of Fort Hare requires a doctoral qualification for appointment as a senior lecturer. In addition to this, the candidate must be able to publish, supervise postgraduate students and develop new courses. ${ }^{2}$

In the United Kingdom, the University of Lancashire has the same strict requirements for appointment as a junior lecturer as the University of Pretoria. Northumbria University in 
Newcastle provides few criteria for appointment as a senior lecturer but specifically mentions a developing body of research as a requirement. To be an associate professor or a professor at this university, one must have an exceptional research record and be recognised as an expert in the field.

At Ulster University in Ireland, to be a junior lecturer one needs to be able to lecture at undergraduate and postgraduate levels, supervise postgraduate students and conduct research (Ulster University 2019, https://www.timeshighereducation.com/unijobs 2019).

Affirmative action measures should be benchmarked against the criteria applied at other tertiary education institutions so as to ensure that they do not constitute a reduction in the criteria for appointment and/or promotion.

A preoccupation with quota-driven targets instead of applying transformation initiatives that are supportive both of the academic project as a whole and of emerging black and white academics "is probably unconstitutional, certainly inhumane and bound to threaten quality" (Bozzoli 2018). Ignoring the important factors necessary to performing the role and functions of an academic, in the case of appointments and promotions at an academic institution by reduction in the qualifying criteria cannot lead to better "service of humanity". Excluding qualifications and competence, experience, legal knowledge, leadership managerial skills and the promotion of efficiency from the equation or applying affirmative action in a manner that is set to punish or prejudice certain employees not falling within a certain group can have no positive outcome.

Nature provides a fitting example of the required developmental process. Butterflies and moths both resort in the order Lepidoptera. These fascinating creatures go through four distinct stages of development (egg, larva, pupa and adult (Hadley 2017), each serving a specific purpose in the process of metamorphosis. The length of time that it takes for a moth or a butterfly to hatch from its egg, develop into a caterpillar, grow big enough and eventually develop into pupae depends on several factors. These include personal traits such as species, environmental factors and accessibility to essential nutrients. In the pupal stage or resting stage when the caterpillar is wrapped in chrysalides (for a butterfly) or a cocoon (for a moth), the caterpillar's body breaks down by means of histolysis. Several changes are initiated through transformative cells and biochemical processes, which reconstruct the tissue from that of a caterpillar into that of a butterfly or a moth. However, the butterfly or moth will emerge from the chrysalides or cocoon only when the time is right. How long this takes depends on triggers such as chemical or hormonal signals and changes in light and temperature. Emerging from the chrysalis or cocoon is also no easy feat: the adult butterfly or moth must eat its way through its pupal cuticle and force its swollen abdomen through a narrow bottleneck opening. This process 
serves to strengthen its shrivelled wings by pumping haemolymph into the veins. Absent this struggle, the butterfly or moth cannot spread its wings and fly (Hadley 2017); these Lepidoptera are left grounded, exposed and, inevitably, they die.

Academics, similarly, must go through different stages of development. As a young academic, learning the ropes particularly by teaching and interacting with undergraduate students is a major component of their work. In time, these interactions with students, peers and learning materials develop in the academic the critical skills required for analytical thinking. Once the junior academic has been exposed sufficiently to the subject area, they become more critical in the way they read information. They think differently, identify problems and begin to propose possible solutions. Having reached this stage, they can write a master's dissertation or attempt to write a research article. Once this hurdle has been crossed, the academic can begin supervising students at an honours and later at a masters level. It may take many years, with several rejected article submissions and a number of embarrassing presentations at conferences to their name, to reach this point. It may take even longer before an academic reaches the stage of development where they can write a doctoral thesis. Most academics will agree that undertaking a doctorate - much like the pupal stage of development in butterflies and moths is a major step in the personal development of an academic. To force someone to embark on such an enterprise when they have not developed the confidence and maturity to write a research article will not necessarily lead to a fully developed staff member or a successful denouement in their career.

Moreover, to expect developing academics to supervise students if they are not a step ahead and not yet able to do sound research themselves, is likely to be a perilous practice. Each phase of development must be navigated by different individuals in accordance with their own aptitude and career paths. It would be glib to deny that the speed or otherwise with which an academic is able to progress through the ranks from junior to senior is influenced by several factors. But it is worth pointing out that these undoubtedly include historic disadvantage and socio-economic circumstances. It is also uncontested that there is strong and justifiable legal and political will dictating the fast-tracking of black academics. However, fast-tracking can have seriously detrimental effects on the development of the individual as an academic. Promoting junior academics to senior posts prematurely also detracts from the value of the achievements of those who, despite having faced adversity (and perhaps because of it), managed to meet the required standards.

Festinger (1957) describes the concept "dissonance" as a state of "psychological discomfort" that arises if people are placed in a situation where they do not believe that they fit. It is "the existence of non-fitting relations among cognitions" (Festinger 1957, 2). Cognitions 
are beliefs regarding oneself, one's behaviour or the environment that one finds oneself in. Festinger argues that dissonance motivates one to reach a state where dissonance itself is reduced. Instead of accepting one's fate and becoming trapped permanently in a situation where the individuals do not belong, very often these individuals develop their skills in a positive manner to escape their circumstances. To lower the bar for certain groups of employees, while at the same time stifling the progress of others, would remove the dissonance and motivation required to progress through the academic ranks for all academics, black and white.

\section{CONCLUSION}

The SAHRC was invited to scrutinise whether the Unisa's EE plan is valid and legal and whether its affirmative action measures are viable. Unfortunately, many of the questions raised during its investigation, including some that are key, were left unanswered. The SAHRC failed, for instance, to make any findings on whether Unisa's EE plan or affirmative action policies violate or infringe upon the human dignity of non-designated employees. It also provided very few recommendations regarding the practical implementation of the sparse suggestions that were made.

The proposed policy amendments that were already being contemplated during the investigation hearings can probably be justified, if not encouraged, by reference to selectively cited aspects of the SAHRC Final Report. The potentially negative implications associated with the affirmative action measures aimed at lowering the bar for certain academics in tertiary education certainly tips the scale in favour of preferring affirmative action measures that are aimed at capacity-building among academics in the designated groups. But just as it will not work to fast-track the development of Lepidoptera species by, for instance, sparing the butterfly or moth the hardship of breaking out of its pupa, it is not possible to skip the stages of development that an academic must traverse to reach the maturity required to perform optimally at senior level. Only those who go through the inevitable trials and tribulations necessary to developing the required skills and attitudes will, when the time is right for them, emerge fully fledged and fly.

The implementation of affirmative action measures in an incorrect manner without considering the potentially devastating consequences for the academic project as a whole can result in much harm being done. In fact, it would threaten the very existence of a small, oppressed minority of which this writer forms part: the developing South African academic.

\section{NOTES}

1. See the definition in s 1 of the EEA: a "designated employer" is an employer who has 50 or more 
workers in its employ, or who employs fewer than 50 but who has a total annual turnover equal to or exceeding the threshold amount as established in Schedule 4 of the EEA. See, too, s 15(2) of the EEA..

2. See the advertised criteria at http://www.ufh.ac.za/jobs; https://www.indeed.co.za/Faculty-of-Law,Stellenbosch-University-jobs?vjk=2ea05119da086d82.

\section{REFERENCES}

Academy of Science of South Africa. 2010. The PhD study consensus report. https://research.za.assaf. org.za (Accessed 13 March 2019).

ASSAf see Academy of Science of South Africa.

Bozzoli, Opinionista Belinda. 2018. What happens when universities start to decay: The case of Unisa. Daily Maverick (13 November 2018). https://www.dailymaverick.co.za/opinionista/2018-11-13what-happens-when-universities-start-to-decay-the-case-of-unisa/ (Accessed 13 March 2019).

Burger, Abrie. 2017. Unisa se personeel in regte se hoop min. Rapport 30 Julie 2017, 9.

CLAW see College of Law.

College of Law. 2016-2020. EE plan.

Department of Labour. 2017. Code of good practice on the preparation, implementation and monitoring of the EE plan. 2017. AK 393 SK 40817 of 28 April 2017. http//www.gponline.co.za (accessed 13 March 2019).

Department of Labour. 2017-2018. Commission for Employment Equity. 17th Annual Report 20162017. http://www.labour.gov.za/DOL/documents/annualreports/Commission\%20for\%20Employment\%20Equity\%20Report/2016-2017/commission-foremployment-equity-report-2016-2017 (accessed 13 March 2019).

Du Plessis, J. V. and M. A. Fouché. 2015. A practical guide to labour law. $8^{\text {th }}$ Edition. LexisNexis.

Festinger, L. 1957. The theory of cognitive dissonance. California: Stanford University Press.

Geldenhuys, J. 2018. ' $n$ Oorweging van verskeie aspekte rakende die prerogatief om werknemers nie te bevorder nie. Litnet Akademies - Regte 15(1).

Gnade, Jeanette. 2018. Unisa: Kleur of meriete. Maroela media 11 May 2018. https://maroelamedia. co.za/debat/meningsvormers/unisa-kleur-of-meriete/ (Accessed 13 March 2019).

Hadley, Debbie. 2017. Life cycle of butterflies and moths. Animals and nature. https://www.thoughtco. com/life-cycle-of-butterflies-and-moths-1968208 (Accessed 13 March 2019).

Maistry, S. M. 2017. Betwixt and between: Liminality and dissonance in developing threshold competences for research supervision in South Africa. South African Journal of Higher Education 31(1): 119-134.

Parliamentary Monitoring Group. 2018. Transformation at public universities in South Africa. SAHRC report Higher education and training. https://pmg.org.za/committee-meeting/26226/ (Accessed 13 March 2019).

SAHRC see South African Human Rights Commission.

South African Human Rights Commission. 2016. SAHRC report: Transformation at public universities in South Africa. https:14//www.sahrc.org.za/home/21/files/SAHRC\%20Report\%20-\%20 Transformation\%20in\%20Public\%20Universities\%20in\%20South\%20Africa.pdf (Accessed 13 March 2019).

South African Human Rights Commission. 2018a. Media advisory: South Africa Human Rights (Gauteng provincial office) reconvenes an investigative hearing into allegations of unfair discrimination, racism, sexism and harassment at Unisa. 12 March 2018. https://www.sahrc.org.za/ (Accessed 13 March 2019).

South African Human Rights Commission. 2018b. Final SAHRC report. Investigation into allegations 
of racial tension, unfair discrimination and harassment at Unisa. Ref No GP/1718/0451.

South African Human Rights Commission. 2018c. Terms of reference. Terms of Reference as amended on 20 and 21 February 2018 for investigation hearing relating to the UNISA College of Law.

Strauss, E. 2006. Generiese riglyne vir die implementering van gelyke geleenthede by 'n groep nieaangewese werknemers. MCom in Human Resources Management dissertation, University of Pretoria. http://repository.up.ac.za/handle/2263/23205 (Accessed 13 March 2019).

Ulster University. 2019. https://www.timeshighereducation.com/unijobs (Accessed 13 March 2019).

United Nations Human Rights Commission (UNHRC). 1969. Status of ratification, Reservations and declarations - South Africa. https://www.ohchr.org/en/professionalinterest/pages/cerd.aspx (Accessed 13 March 2019).

Vice, S. 2015. Dignity and equality in Barnard. (VII) Constitutional Court Review. https://www.constitutionalcourtreview.co.za/wp-content/uploads/2018/10/Dignity-and-EqualityCCR-VII-2015.pdf (Accessed 13 March 2019).

Waghid, Y. 2015. Are doctoral studies in South African higher education being put at risk? South African Journal of Higher Education 29(5): 1-19.

\section{Case law}

Du Preez v Minister of Justice and Constitutional Development 2006 (3) All SA 271 (SE)

Gordon v Department of Health, KwaZulu-Natal [2004] 7 BLLR 708 (AH)

Lotter v SA Police Service 2005 (26) ILJ 578 (BCA)

McInnes $v$ Technikon Natal [2000] 6 BLLR 701 (LC)

Monyakeni v SA Police Service 2008 (29) ILJ 3111 (BCA)

Ncane v Lyster (2017) 38 ILJ 907 (LAC)

PSA v Minister of Justice (1997) 18 ILJ 241 (T)

SAPS v Solidarity obo Barnard (Police and Prisons Civil Rights Union as Amicus Curiae) 2014 (6) SA 123 (CC)

SAPS v Zandberg 2010 (2) BLLR 194 (A)

Solidarity obo Barnard v South African Police Service 2014 (2) SA 1 (SCA)

Solidarity and Others v Department of Correctional Services and Others 2016 (5) SA 594 (CC)

Stoman v Minister of Safety and Security 2002 (3) SA 468 (T)

\section{Legislation}

Constitution of the Republic of South Africa, 1996.

Employment Equity Act 55 of 1998 (EEA).

Higher Education Act 101 of 1997.

Higher Education Amendment Act 9 of 2016.

International Convention on the Elimination of All Forms of Racial Discrimination, 1969. 